International Journal of Supply Chain

Management (IJSCM)

INFLUENCE OF STRATEGIC PROCUREMENT ON PERFORMANCE OF WORLD BANK FUNDED PROJECTS IN NAIROBI CITY COUTY, KENYA

Dennis Onserio, Dr. Noor Ismail and Dr. Entere Kirima

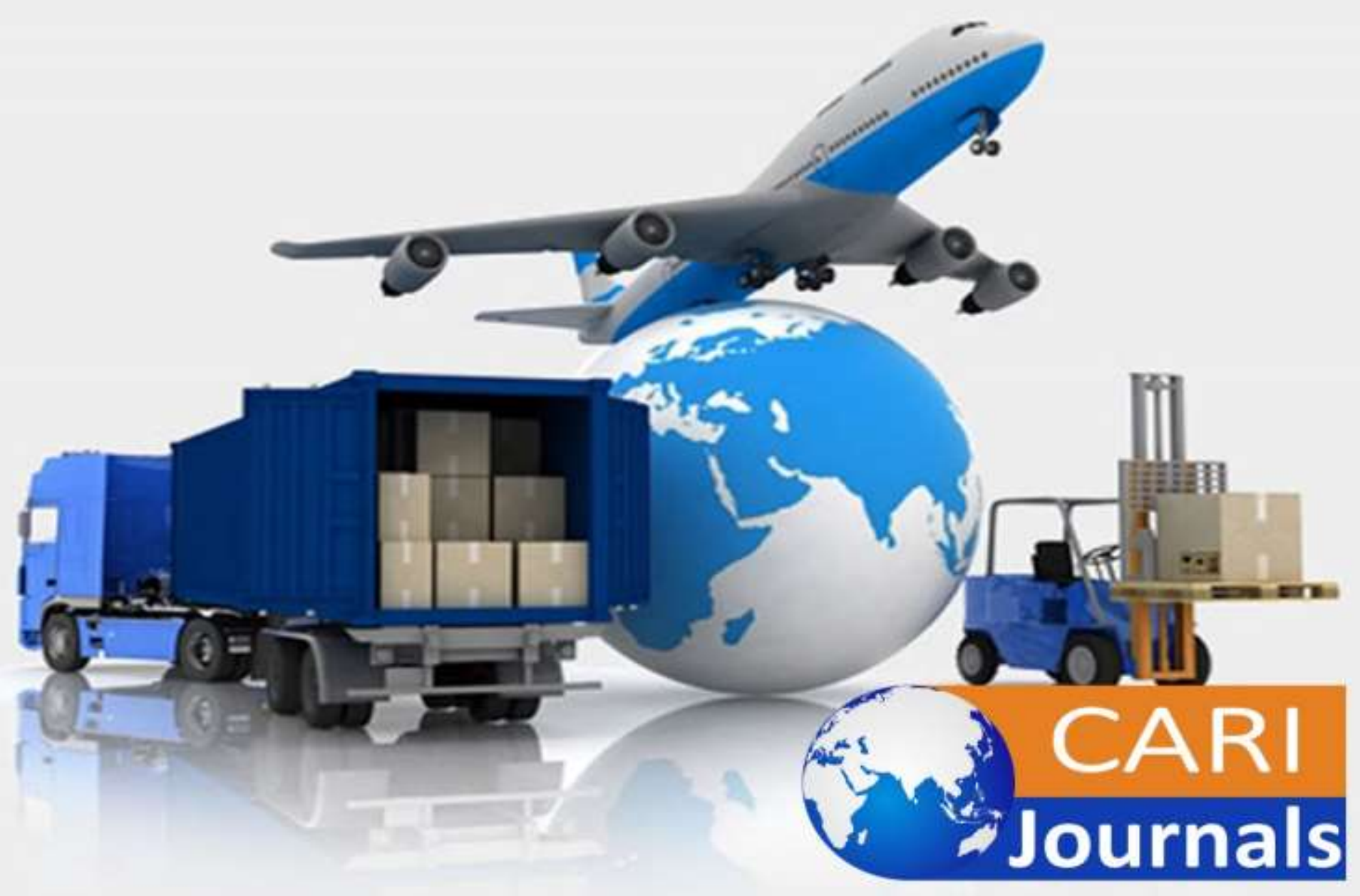




\title{
INFLUENCE OF STRATEGIC PROCUREMENT ON PERFORMANCE OF WORLD BANK FUNDED PROJECTS IN NAIROBI CITY COUTY, KENYA
}

\author{
1* Dennis Onserio \\ 1 *Post Graduate Student,Department of Procurement and Logistics \\ Jomo Kenyatta University Of Agriculture And Technology \\ *Corresponding Author's E-mail: dennisonserio@gmail.com \\ ${ }^{2 *}$ Dr. Noor Ismail \\ Lecturer, Department of Procurement and Logistics, \\ Jomo Kenyatta University Of Agriculture And Technology \\ $3^{*}$ Dr. Entere Kirima \\ Lecturer, School Of Business And Economics, \\ Cooperative University of Kenya
}

\begin{abstract}
Purpose: The purpose of the study was to examine influence of strategic procurement on performance of world bank funded projects in nairobi city couty, Kenya

Methodology: This research study adopted a descriptive research design approach. The researcher preferred this method because it allows an in-depth study of the subject. To gather data, structured questionnaire was used to collect data from 120 officers working for the implementing agencies spread in various World Bank funded projects in Nairobi City County. . As a rule of thumb census was used because the total population is less than 200. Once collected, data was analyzed using descriptive and inferential statistics. Quantitative data was analyzed using multiple regression analysis. The qualitative data generated was analyzed by use of Statistical Package of Social Sciences (SPSS) version 20.

Results: The response rate of the study was $87 \%$. The study findings of the study indicated that vendor optimization, outsourcing, information technology adoption and total quality management had a positive impact on the performance of World Bank funded projects in Nairobi City County, Kenya such as general cost reduction of projects, greater customer satisfaction and timely delivery of the projects.

Unique contribution to theory, practice and policy: the study recommended that public institutions should embrace strategic procurement so as to improve performance and further research should to be carried out in other institutions to find out if the same results can be obtained since the findings may not be applicable to all other counties, or implementing agencies in Kenya and the world at large.
\end{abstract}


International Journal of Supply Chain and Logistics

ISSN 2520-3983 (Online)

Vol. 5, Issue No.2, pp 1 -20, 2021

$\underline{\text { www.carijournals.org }}$

Keywords: vendor optimization, outsourcing, information technology adoption, total quality management

\subsection{Introduction}

This study investigated the effect of strategic procurement on performance of World Bank Funded Projects in Naiobi City County, Kenya. To this end, this chapter builds the case by introducing the problem warranting the study. This chapter presents; the background of the study, problem statement, objectives, research questions, importance of the study, the scope of the study and limitations of the study.

Procurement in urban development sectors is a fast growing partnership and incurs one of the largest expenditures from procurement of supplies, and services. World Bank funded projects also represent the largest cost component of national sector expenditures and development supplies account for one of the largest costs to World Bank funded projects (OECD, 2011). Organizations have turned into the strategy for cutting cost and improving quality in order to increase the efficiency of the procurement function and reduce operational costs.

Procurement is concerned with how organizations spend tax payers' money in goods and services (Hall, 2009). Ordinarily, public procurement should be guided by principles of transparency and accountability and achieving value for money for citizens and tax payers. It is an effective means for reducing waste and corruption thereby increasing public confidence. A sound procurement system needs to have good procurement laws and regulations leading to procurement efficiency (Mentzer, 2010).

The Kenyan government developed the Public Procurement and Disposal Act, 2005 and Regulations 2006 to put in place procedures for efficient public procurement and for the disposal of unserviceable, obsolete or surplus stores, assets and equipment by public entities (Amayi, 2010). Similar to other instruments, the Act characterizes public procurement through well-defined regulations open to public scrutiny, clear, standardized tender documents containing complete information and equal opportunity for all in the bidding process (Hall, 2009). But vested interests, corruption and lack of enough information to suppliers on their obligation in the fulfillment of tenders have affected many public procurement processes.

The World Bank Group was founded in 1944 to provide loans to help countries devastated by World War II to reconstruct. The organization later changed its focus from reconstruction to development. Today the Bank Group's work touches nearly every sector that is important to fighting poverty, supporting economic growth, and ensuring sustainable gains in the quality of people's lives in developing countries. While sound project selection and design remain paramount, the Bank Group recognizes a wide range of factors that are critical to successeffective institutions, sound policies, continuous learning through evaluation and knowledgesharing, and partnership, including with the private sector (World Bank, 2020)

The World Bank's procurement policy governs how clients acquire works, goods, and services under projects financed by the Bank, and the roles and responsibilities of the Bank and clients in that process. The world has changed, and public procurement practices have changed with it. Similarly, the Bank's clients have changed, along with their institutional capacity. The countries 
International Journal of Supply Chain and Logistics

ISSN 2520-3983 (Online)

Vol. 5, Issue No.2, pp 1 -20, 2021

$\underline{\text { www.carijournals.org }}$

that borrow from the Bank spend several trillion US dollars annually on public procurement. The Bank finances less than one percent of that amount (World Bank, 2013).

World Bank operations are dominated by investment lending. Bank procurement policies and processes affect the development impact of Bank lending and influence public procurement practices. The Bank seeks to ensure that its funds are used for the purpose intended and that they support development effectively and efficiently. Thus, the extent to which Bank investment lending procurement policies support the effectiveness of Bank lending have a deep influence on development outcomes (IEG, 2014).

The World Bank has recently updated their procurement framework to focus on value for money, to differentiate bids and to ensure the best results for the project. The focus will shift from lowest evaluated compliant bids to provide the best overall value for money, taking into account quality, cost and other relevant factors to the projects (IE, 2016).

\subsection{Statement of the Problem}

Ideally, public entities support the Government of Kenya's policy of ensuring that services are easily accessible and affordable to $90 \%$ of Kenyan citizens hence the reason for the national and county government's heavy funding amounting to Ksh. 152 Billion through annual budgetary allocation that aims at ensuring that the World Bank funded projects have a steady supply of supplies. Despite this, public entities in Kenya have over time, been blamed for poor service delivery and performance in general. Procurement in World Bank funded projects is important as these organizations use taxpayer money for their operations (Deloitte, 2012).

According to an OECD Report (2011) the public entities play a major role in the development status and index of a country through provision of public services and very useful engines to promoting development. In Kenya, $80 \%$ of public entities have been blamed for poor services emanating from stock outs, poor hygiene and insufficient supplies (USAID, 2012). Run away corruption and mismanagement in procurement are the challenges that have been cited as leading to lack of an improved performance and service delivery among state entities such as housing and urban planning and development (PPOA, 2009).

According to a report by Center for Economic Solutions (2014) on public entities in Kenya, losses of Kshs 66,561,900.00 were incurred through irregular procurements in financial year (FY) 2017/2018. This raises questions on the level of performance of World Bank funded projects' in public institutions (MoH, 2013). According to a spend analysis report by Kirungu (2014), public entities lost Ksh 350 million due to poor procurement management, which consequently affected its performance as a whole.

A research carried out on the state of service delivery in housing and urban planning and development in Kenya by World Bank (2014) revealed that $80 \%$ of public entities have poor performance. The study also found that the public preferred fully World Bank funded projects to publicly funded projects due to the perception that World Bank funded projects have a high completion rate (KIPPRA, 2010). Locally, Abdifatah (2012) did a study on procurement planning and procurement strategies and concluded that they have direct positive impact on the performance of humanitarian organizations in delivery of relief and emergency services. 
While much research has focused on the problems facing procurement in World Bank funded projects in Kenya, not much research has been done to study the role of strategic procurement and performance of World Bank funded projects in Nairobi City County, Kenya. It is against this back drop that this study aims at assessing the role of strategic procurement on performance of World Bank funded projects implemented in Nairobi City County, Kenya.

\subsection{Objectives of the Study}

i. To assess the effect of vendor optimization on performance of World Bank funded projects in Kenya.

ii. To establish the effect of outsourcing on performance of World Bank funded projects in Kenya.

iii. To determine the effect of information technology integration on performance of World Bank funded projects in Kenya.

iv. To evaluate the effect of total quality management on performance of World Bank funded projects in Kenya.

\subsection{LITERATURE REVIEW}

\subsection{Partnership Theory}

This theory was developed in the 17th century by philosopher Hobbes who argued that in supply chain, the common model through which theorists study the relationship between supplier and buyer is known as the partnership theory (Lambert, 2011). In its basic nature, the partnership model depicts the buyer and supplier as partners with a common interest which is customer satisfaction (Koh, 2013). Vendor optimization is a business relationship based on mutual trust, openness, shared risks and rewards that enables an organization gain competitive advantage leading in the company achieving a performance that's far much greater than the firm would have achieved when operating as single entities (Palevich, 2012). The theory further states that any vendor optimization strategy is always based on value and present for each other. The solid and long term relationship simply implies involving vendors' early and continuous improvement of the organization performance (Fawcett, 2009). Vendor optimization according to Shapiro (2009), increases company efficiency through way of cooperative; both parties obtain cost reduction which leads to price reduction and therefore increasing the market share profit margin as well. This leads to a company gaining a competitive edge and efficiency (Water, 2013).

The partnership theory has three elements which are drivers, facilitators' and used components. The drivers each party must have a driver strong enough to provide them with realistic expectation of significance benefit through strengthening of the relationship (Davila, 2009). Facilitators on the other have included corporate compatibility, mutuality, managerial philosophy and techniques and symmetry. The final element is the components which are the factors than can be controlled in a partnership by the management. They include consolidation of contracts, strategic alliances, communications, risk/reward sharing, trust and commitment, supplier development, scope and financial investment (Eckert, 2012). 
Vendor optimization is founded on these elements in that it is a business relationship where a buyer engages a small number of suppliers as possible, and sometimes a single supplier, for his requirements so as to make their partnership a less costly affair to manage but with each party giving an assurance of meeting his contractual obligations. In conclusion in order to gain leadership position against your competitors and ensure the organization grows partnership; vendor optimization can be used to achieve the above.

\subsection{Strategic Procurement}

\subsubsection{Vendor Optimization}

Vendor optimization in this study was considered as a strategic procurement variable that influences performance of World Bank funded projects. The attributes of vendor optimization which were taken into consideration in this study are: strategic collaborations, early supplier involvement and consolidation of contracts. Vendor optimization starts with rationalization, a strategic initiative, and supporting processes to initially reduce static or limited-use suppliers; moving beyond simply reducing the number of suppliers and spending more time with fewer suppliers to reduce costs (Aberdeen Group, 2014). It then requires critical lean supply chain methods and tools to systematically optimize the supply base size, which is dependent upon supplier performance.

\subsubsection{Outsourcing}

Outsourcing in this study was considered as a strategic procurement variable that influences performance of World Bank funded projects. The attributes of outsourcing which were taken into consideration in this study are: vendor performance management, core versus noncore spend monitoring and realized versus contracted savings comparison. Outsourcing is a common practice among both private and World Bank funded projects and is a major element in business strategy (Onyango, 2011). Perhaps most organizations now outsource some of the functions they used to perform themselves. Due to widespread outsourcing practices, it has become a frequent topic in the literature. Numerous reasons why outsourcing is initiated have been identified by researchers. Organizations may expect to achieve many different benefits through successful outsourcing, although there are significant risks that may be realized if outsourcing is not successful (Andrew, 2012).

\subsubsection{Information Technology Integration}

Information technology adoption in this study was considered as a strategic procurement variable that influences performance of World Bank funded projects. The attributes of information technology adoption which were taken into consideration in this study are: e-sourcing, e-tendering and electronic data interchange. Nowadays organizations have to increase their core competency and competitive advantage with an upward trend in order to sustain in the market (Davila, 2009). Therefore, they have to employ new technologies and adopt themselves with the new system permanently.

\subsubsection{Total Quality Management}

Total quality management in this study was considered as a strategic procurement variable that influences performance of World Bank funded projects. The attributes of total quality management 
International Journal of Supply Chain and Logistics

ISSN 2520-3983 (Online)

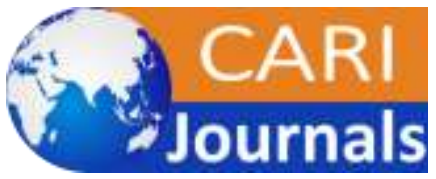

Vol. 5, Issue No.2, pp 1 -20, 2021

www.carijournals.org

which were taken into consideration in this study are: process management, continuous improvement and customer focus. Total Quality Management (TQM) is considered an important catalyst in the performance of organizations world over. This is why the TQM concept has captured the attention of all sides of commerce and industry, as well as that of academics.

\subsection{Operationalization of Variables}

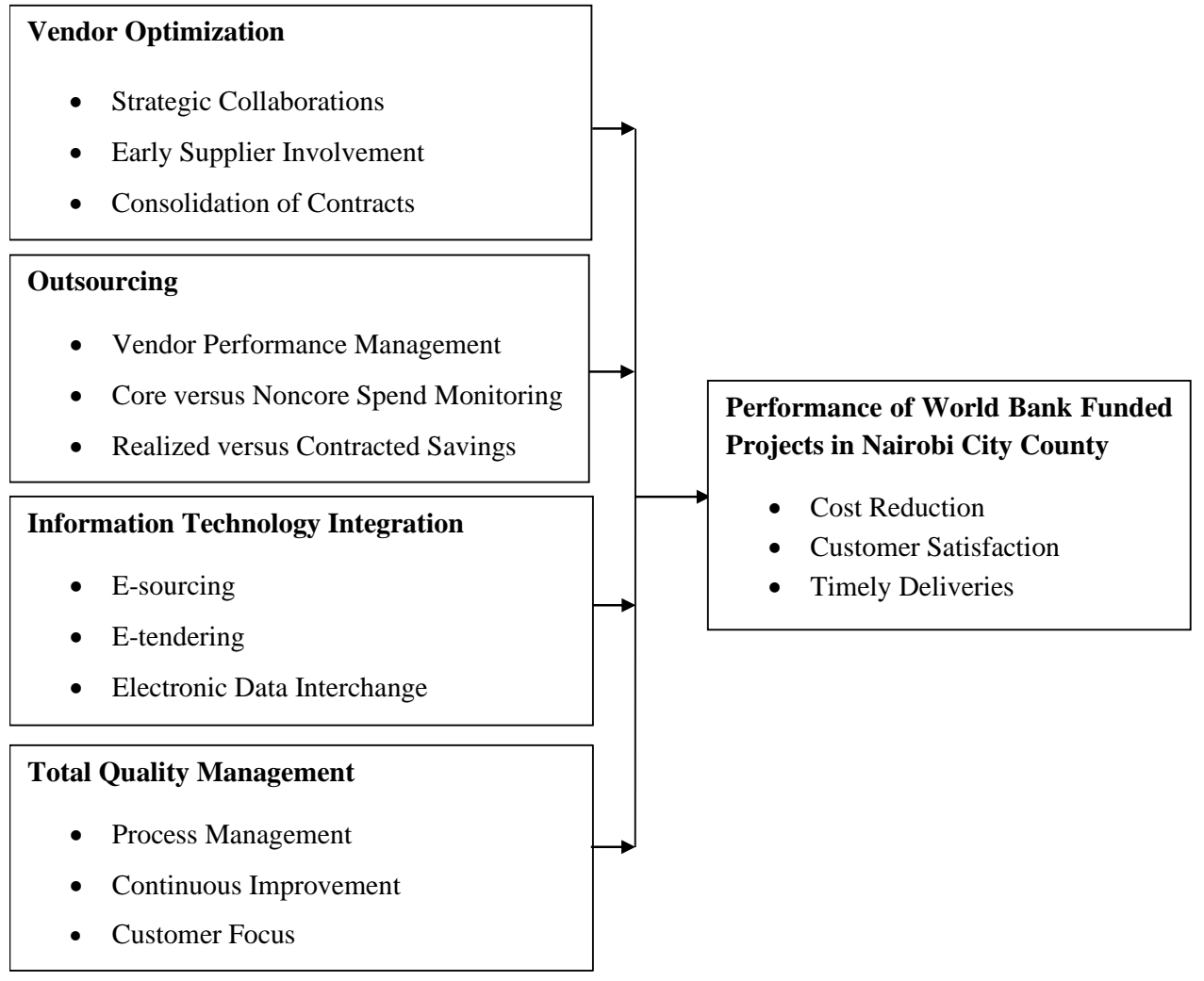

Independent Variables

Dependent Variable

Figure 1: Conceptual Framework 3.0 METHODOLOGY

This research study adopted a descriptive research design approach. The researcher preferred this method because it allows an in-depth study of the subject. To gather data, structured questionnaire was used to collect data from 120 officers working for the implementing agencies spread in various World Bank funded projects in Nairobi City County. . As a rule of thumb census was used because the total population is less than 200. Once collected, data was analyzed using descriptive and inferential statistics. Quantitative data was analyzed using multiple regression analysis. The qualitative data generated was analyzed by use of Statistical Package of Social Sciences (SPSS) version 20 . 
International Journal of Supply Chain and Logistics

ISSN 2520-3983 (Online)

Vol. 5, Issue No.2, pp 1 -20, 2021

www.carijournals.org

The research used a multiple regression model.

$\mathrm{Y}=\beta 0+\beta 1 \mathrm{X} 1+\beta 2 \mathrm{X} 2+\beta 3 \mathrm{X} 3+\beta 4 \mathrm{X} 4+\varepsilon$

Where:

$\mathrm{Y} \quad=$ Performance of World Bank Funded Projects

$\beta 0 \quad=$ Constant

$\beta 1, \beta 2, \beta 3, \beta 4=$ Beta Coefficients

$\mathrm{X} 1=$ Vendor Optimization

$\mathrm{X} 2=$ Outsourcing

X3 = Information Technology Adoption

X4 = Total Quality Management

$\varepsilon=$ Error Term

\section{0 RESULTS FINDINGS}

\subsection{Descriptive Statistics}

\subsubsection{Vendor Optimization}

The first objective of the study was to assess the influence of vendor optimization on performance of World Bank funded projects in Kenya. The respondents were asked to indicate to what extent vendor optimization had an influence on performance of World Bank funded projects in Kenya. Results indicated that majority of the respondents $27 \%$ agreed that it was to a very effective, $25 \%$ said that it was effective, $29 \%$ said it was somehow effective, while ineffective was at $19 \%$.

\section{Vendor Optimization}

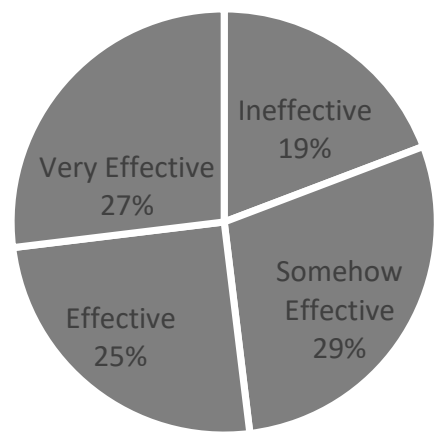

Figure 2: Vendor Optimization 
The respondents were also asked to comment on statements regarding vendor optimization influence on performance of World Bank funded projects in Kenya. The responses were rated on a likert scale and the results presented in Table 4.6 below. It was rated on a 5 point likert scale ranging from; $1=$ strongly disagree to $5=$ strongly agree. The scores of 'strongly disagree' and 'disagree' have been taken to represent a statement not agreed upon, equivalent to mean score of 0 to 2.5. The score of 'neutral' has been taken to represent a statement agreed upon, equivalent to a mean score of 2.6 to 3.4. The score of 'agree' and 'strongly agree' have been taken to represent a statement highly agreed upon equivalent to a mean score of 3.5 to 5 .

The respondents were asked to indicate their responses on influence of vendor optimization on performance of World Bank funded projects in Kenya. The results revealed that majority of the respondent with a mean of (4.13) agreed with the statement that Strategic collaborations plays a significant role in cost reduction. The measure of dispersion around the mean of the statements was 0.94 indicating the responses were varied. The result revealed that majority of the respondent as indicated by a mean of (4.27) agreed with the statement Early supplier involvement plays a significant role in cost reduction. The standard deviation for was 0.968 showing a variation. The result revealed that majority of the respondent (4.55) agreed with the statement that Consolidation of contracts plays a significant role in cost reduction. The results were varied as shown by a standard deviation of 0.5 .

The average response for the statements on Strategic collaborations plays a significant role in improving customer satisfaction was (4.22). The results were varied as shown by a standard deviation of 0.955 . The average response for the statements on Early supplier involvement plays a significant role in improving customer satisfaction was (4.4). The results were varied as shown by a standard deviation of 0.704 . The result revealed that majority of the respondent with a mean of (4.46) agreed with the statement that Consolidation of contracts plays a significant role in improving customer satisfaction. The measure of dispersion around the mean of the statements was 0.787 indicating the responses were varied.

The result revealed that majority of the respondent as indicated by a mean of (4.44) agreed with the statement Strategic collaborations plays a significant role in attaining timely deliveries. The standard deviation for was 0.786 showing a variation. The result revealed that majority of the respondent (4.21) agreed with the statement that Early supplier involvement plays a significant role in attaining timely deliveries. The results were varied as shown by a standard deviation of 0.942. The average response for the statements on Consolidation of contracts plays a significant role in attaining timely deliveries was (4.01). The results were varied as shown by a standard deviation of 0.81 . 
International Journal of Supply Chain and Logistics

ISSN 2520-3983 (Online)

Vol. 5, Issue No.2, pp 1 -20, 2021

www.carijournals.org

Table 1: Vendor Optimization

\begin{tabular}{l} 
Statements \\
\hline $\begin{array}{l}\text { Strategic collaborations plays a significant role in cost } \\
\text { reduction }\end{array}$
\end{tabular}

reduction

4.10

0.94

Early supplier involvement plays a significant role in cost reduction

Consolidation of contracts plays a significant role in cost reduction

Strategic collaborations plays a significant role in improving customer satisfaction

Early supplier involvement plays a significant role in improving customer satisfaction

Consolidation of contracts plays a significant role in improving customer satisfaction

Strategic collaborations plays a significant role in attaining timely deliveries

Early supplier involvement plays a significant role in attaining timely deliveries

Consolidation of contracts plays a significant role in attaining timely deliveries

$4.11 \quad 1.096$

\section{Average}

4.01

0.81

\subsubsection{Outsourcing}

The second objective of the study was to establish the influence of outsourcing on performance of World Bank funded projects in Kenya. The respondents were asked to indicate to what extent outsourcing influenced performance of World Bank funded projects in Kenya. Results indicated that $25 \%$ of the respondents noted that it was to a very great extent, $27 \%$ said that it was to a great extent, 35\% said it was moderate, while little extent and not all were at 5 and $8 \%$ respectively. 


\section{Outsourcing}

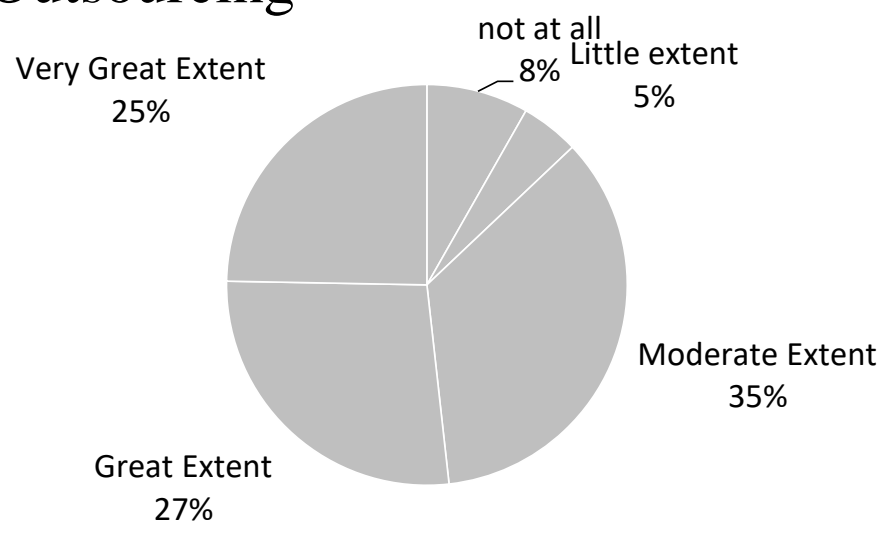

\section{Figure 3: Outsourcing}

The respondents were also asked to comment on statements regarding outsourcing on performance of World Bank funded projects in Kenya. The results revealed that majority of the respondent with a mean of (3.58) agreed with the statement that Vendor performance management rating plays a significant role in cost reduction. The measure of dispersion around the mean of the statements was 1.0 indicating the responses were varied. The result revealed that majority of the respondent as indicated by a mean of (3.63) agreed with the statement Core versus noncore spend monitoring plays a significant role in cost reduction. The standard deviation for was 0.9 showing a variation. The result revealed that majority of the respondent (3.6) agreed with the statement that Realised versus contracted savings comparison percentage plays a significant role in cost reduction. The results were varied as shown by a standard deviation of 0.7 .

The average response for the statements on Vendor performance management rating plays a significant role in improving customer satisfaction was (3.45). The results were varied as shown by a standard deviation of 1.2. The average responses for the statements on Core versus noncore spend monitoring plays a significant role in improving customer satisfaction was (3.5). The results were varied as shown by a standard deviation of 1.0. The results revealed that majority of the respondent with a mean of (3.61) agreed with the statement that Realised versus contracted savings comparison percentage plays a significant role in improving customer satisfaction. The measure of dispersion around the mean of the statements was 0.6 indicating the responses were varied.

The result revealed that majority of the respondent as indicated by a mean of (4.17) agreed with the statement Vendor performance management rating plays a significant role in attaining timely deliveries. The standard deviation for was 0.8 showing a variation. The result revealed that majority of the respondent (3.63) agreed with the statement that Core versus noncore spend monitoring plays a significant role in attaining timely deliveries. The results were varied as shown by a standard deviation of 0.8. The average response for the statements on Realised versus contracted savings comparison percentage plays a significant role in attaining timely deliveries was (3.66). The results were varied as shown by a standard deviation of 1 . 
International Journal of Supply Chain and Logistics

ISSN 2520-3983 (Online)

Vol. 5, Issue No.2, pp 1 -20, 2021

www.carijournals.org

Table 2: Outsourcing

Statements

Vendor performance management rating plays a significant role in cost reduction

Core versus noncore spend monitoring plays a significant role in cost reduction

Realised versus contracted savings comparison percentage plays a significant role in cost reduction

Vendor performance management rating plays a significant role in improving customer satisfaction

Core versus noncore spend monitoring plays a significant role in improving customer satisfaction

Realised versus contracted savings comparison percentage plays a significant role in improving customer satisfaction

Vendor performance management rating plays a significant role in attaining timely deliveries

Core versus noncore spend monitoring plays a significant role in attaining timely deliveries

Realised versus contracted savings comparison percentage plays a significant role in attaining timely deliveries
Mean

3.61

0.6

Average 3.77 1.134

\subsubsection{Information Technology Adoption}

There was also need to establish influence of information technology adoption on performance of World Bank funded projects in Kenya as the third objective. Results indicated that majority of the respondents $47 \%$ agreed that it was to a very great extent, $45 \%$ said that it was to a great extent, $2 \%$ said it was moderate; little extent was $2 \%$ and not all at $4 \%$. 


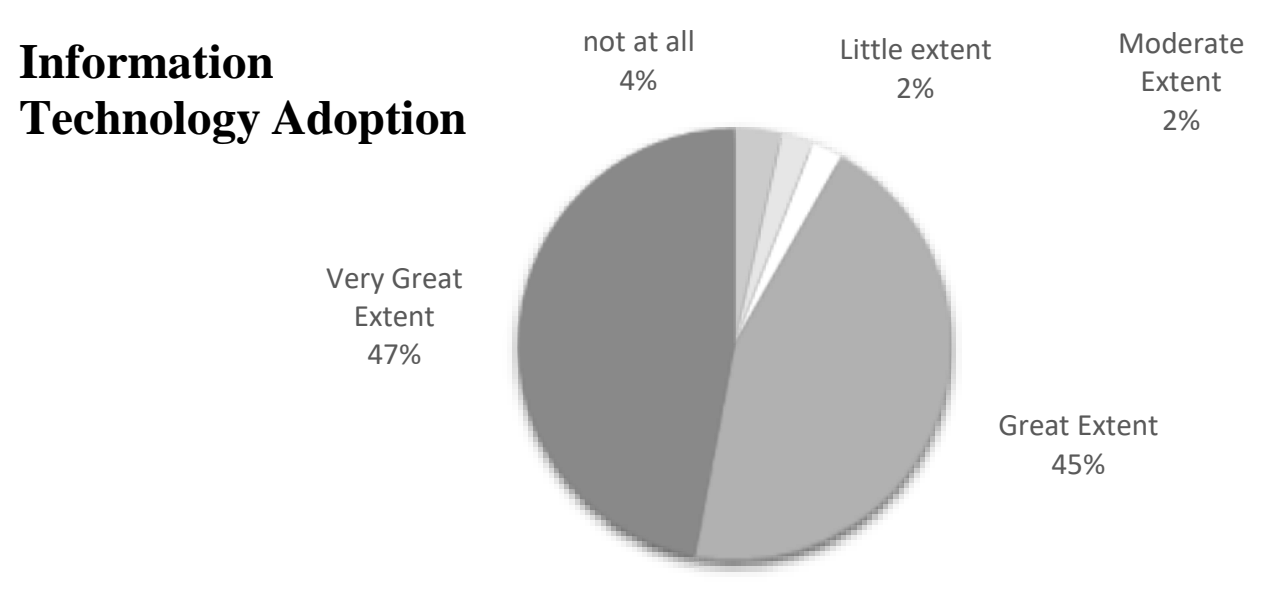

\section{Figure 4: Information Technology Adoption}

The respondents were asked to indicate their levels of agreement on statements regarding strategic partnership. The results revealed that majority of the respondent with a mean of (3.8) agreed with the statement that E-sourcing plays a significant role in cost reduction. The measure of dispersion around the mean of the statements was 0.9 indicating the responses were varied. The result revealed that majority of the respondent as indicated by a mean of (4.9) agreed with the statement E-tendering plays a significant role in cost reduction. The standard deviation for was 0.9 showing a variation. The result revealed that majority of the respondent (3.4) agreed with the statement that Electronic data interchange plays a significant role in cost reduction. The results were varied as shown by a standard deviation of 1.3.

The average response for the statements on E-sourcing plays a significant role in improving customer satisfaction was (3.6). The results were varied as shown by a standard deviation of 1.2. The average response for the statements on E-tendering plays a significant role in improving customer satisfaction was (4.1). The results were varied as shown by a standard deviation 0.8. The results revealed that majority of the respondent with a mean of (4.1) agreed with Electronic data interchange plays a significant role in improving customer satisfaction. The measure of dispersion around the mean of the statements was 0.9 indicating the responses were varied.

The result revealed that majority of the respondent as indicated by a mean of (4) agreed with the statement E-sourcing plays a significant role in attaining timely deliveries. The standard deviation for was 1 showing a variation. The result revealed that majority of the respondent (4.2) agreed with the statement that E-tendering plays a significant role in attaining timely deliveries. The results were varied as shown by a standard deviation of 0.8 . The average response for the statements on Electronic data interchange plays a significant role in attaining timely deliveries was (3.9). The results were varied as shown by a standard deviation of 0.9. 
International Journal of Supply Chain and Logistics

ISSN 2520-3983 (Online)

Vol. 5, Issue No.2, pp 1 -20, 2021

www.carijournals.org

Table 3: Information Technology Adoption

\begin{tabular}{lcc}
\hline Statements & Mean & Std. Deviation \\
\hline E-sourcing plays a significant role in cost reduction & 3.8 & 0.9 \\
$\begin{array}{l}\text { E-tendering plays a significant role in cost reduction } \\
\text { Electronic data interchange plays a significant role in cost }\end{array}$ & 3.9 & 0.9 \\
reduction & 3.4 & 1.3 \\
$\begin{array}{l}\text { E-sourcing plays a significant role in improving customer } \\
\text { satisfaction }\end{array}$ & 3.6 & 1.2 \\
$\begin{array}{l}\text { E-tendering plays a significant role in improving customer } \\
\text { satisfaction }\end{array}$ & 4.1 & 0.8 \\
$\begin{array}{l}\text { Electronic data interchange plays a significant role in } \\
\text { improving customer satisfaction }\end{array}$ & 4.1 & 0.9 \\
$\begin{array}{l}\text { E-sourcing plays a significant role in attaining timely deliveries } \\
\begin{array}{l}\text { E-tendering plays a significant role in attaining timely } \\
\text { deliveries }\end{array}\end{array}$ & 4.0 & 1.0 \\
$\begin{array}{l}\text { Electronic data interchange plays a significant role in attaining } \\
\text { timely deliveries }\end{array}$ & 3.9 & 0.9 \\
\begin{tabular}{l} 
Average \\
\hline
\end{tabular} & $\mathbf{3 . 8}$ & $\mathbf{0 . 9}$ \\
\hline
\end{tabular}

\subsubsection{Total Quality Management}

There was also need to establish the influence of total quality management on performance of World Bank funded projects in Kenya. Results also showed that $3 \%$ of respondents indicated to very great extent, great extent was at $12 \%$, moderate extent was $37 \%$, while little extent was at $27 \%$ and not at all was at $21 \%$. 


\section{Total Quality Management}

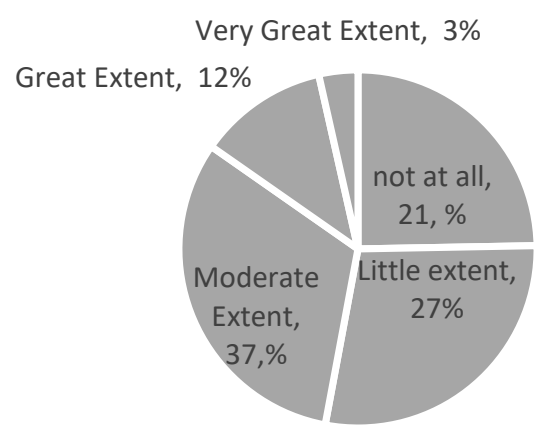

\section{Figure 5: Total Quality Management}

The respondents were asked to indicate their views on total quality management. The results revealed that majority of the respondent with a mean of (4.5) agreed with the statement that Process management plays a significant role in cost reduction. The measure of dispersion around the mean of the statements was 0.5 . The result revealed that majority of the respondent as indicated by a mean of (3.9) agreed with the statement Continuous improvement plays a significant role in cost reduction the standard deviation for was 0.8 showing a variation. The result revealed that majority of the respondent (3.2) agreed with the statement that Customer focus plays a significant role in cost reduction. The results were varied as shown by a standard deviation of 1.4

The average response for the statements on Process management plays a significant role in improving customer satisfaction was (4.5). The results were varied as shown by a standard deviation of 0.5. The average response for the statements on Continuous improvement plays a significant role in improving customer satisfaction was (4.4). The results were varied as shown by a standard deviation 0.6. The results revealed that majority of the respondent with a mean of (4.4) agreed with the statement Customer focus plays a significant role in improving customer satisfaction. The measure of dispersion around the mean of the statements was 0.9 indicating the responses were varied.

The result revealed that majority of the respondent as indicated by a mean of (4.3) agreed with the statement Process management plays a significant role in attaining timely deliveries. The standard deviation for was 0.7 showing a variation. The result revealed that majority of the respondent (4.5) agreed with the statement that Continuous improvement plays a significant role in attaining timely deliveries. The results were varied as shown by a standard deviation of 1.0. The average response for the statements on Customer focus plays a significant role in attaining timely deliveries was (4.1). The results were varied as shown by a standard deviation of 1.0. 
International Journal of Supply Chain and Logistics

ISSN 2520-3983 (Online)

Vol. 5, Issue No.2, pp 1 -20, 2021

$\underline{\text { www.carijournals.org }}$

Table 4: Total Quality Management

\begin{tabular}{llc}
\hline Statements & Mean & Std. Deviation \\
\hline Process management plays a significant role in cost reduction & 4.5 & 0.5 \\
$\begin{array}{l}\text { Continuous improvement plays a significant role in cost reduction } \\
\text { Customer focus plays a significant role in cost reduction }\end{array}$ & 0.9 \\
$\begin{array}{l}\text { Process management plays a significant role in improving } \\
\text { customer satisfaction }\end{array}$ & 4.5 & 0.5 \\
$\begin{array}{l}\text { Continuous improvement plays a significant role in improving } \\
\text { customer satisfaction }\end{array}$ & 4.4 & 0.6 \\
$\begin{array}{l}\text { Customer focus plays a significant role in improving customer } \\
\text { satisfaction }\end{array}$ & 4.4 & 0.9 \\
$\begin{array}{l}\text { Process management plays a significant role in attaining timely } \\
\text { deliveries }\end{array}$ & 4.3 & 0.7 \\
$\begin{array}{l}\text { Continuous improvement plays a significant role in attaining } \\
\text { timely deliveries }\end{array}$ & 4.2 & 1.0 \\
$\begin{array}{l}\text { Customer focus plays a significant role in attaining timely } \\
\text { deliveries }\end{array}$ & 4.1 & 1.0 \\
\begin{tabular}{l} 
Average \\
\hline
\end{tabular} & $\mathbf{4 . 2}$ & $\mathbf{0 . 8}$ \\
\hline
\end{tabular}

\subsection{Correlation Analysis}

Correlation analysis was used to determine both the significance and degree of association of the variables and also predict the level of variation in the dependent variable caused by the independent variables. The correlation summary shown in Table 4.10 indicates that the associations between each of the independent variables and the dependent variable were all significant at the $95 \%$ confidence level. The correlation analysis to determine the relationship between strategic procurement affecting performance of World Bank funded projects in Kenya, Pearson correlation coefficient computed and tested at $5 \%$ significance level.

The results indicate that there is a positive relationship $(\mathrm{r}=.509)$ between vendor optimization and performance of World Bank funded projects in Kenya. In addition, the researcher found the relationship to be statistically significant at $5 \%$ level $(\mathrm{p}=0.000,<0.05)$. The results also indicate that there is a positive relationship ( $\mathrm{r}=.398)$ between outsourcing and performance of World Bank funded projects in Kenya. In addition, the researcher found the relationship to be statistically significant at $5 \%$ level $(\mathrm{p}=0.000,<0.05)$. 
The results indicate that there is a positive relationship ( $\mathrm{r}=.678)$ between information technology adoption and performance of World Bank funded projects in Kenya. In addition, the researcher found the relationship to be statistically significant at $5 \%$ level $(\mathrm{p}=0.000,<0.05)$. The results indicate that there is a positive relationship ( $\mathrm{r}=.685)$ between total quality management and performance of World Bank funded projects in Kenya. In addition, the researcher found the relationship to be statistically significant at $5 \%$ level $(\mathrm{p}=0.000,<0.05)$. Hence, it is evident that all the independent variables could explain the changes in performance of World Bank funded projects in Kenya, on the basis of the correlation analysis.

Table 5: Summary of Pearson's Correlations

\begin{tabular}{|c|c|c|c|c|c|c|}
\hline Correlations & & $\begin{array}{l}\text { Vendor } \\
\text { Optimizati } \\
\text { on }\end{array}$ & Outsourcing & $\begin{array}{l}\text { Information } \\
\text { Technology } \\
\text { Adoption }\end{array}$ & $\begin{array}{l}\text { Total Quality } \\
\text { Management }\end{array}$ & $\begin{array}{l}\text { Performanc } \\
\text { e of World } \\
\text { Bank } \\
\text { funded } \\
\text { projects }\end{array}$ \\
\hline $\begin{array}{l}\text { Vendor } \\
\text { Optimization }\end{array}$ & $\begin{array}{l}\text { Pearson } \\
\text { Correlation }\end{array}$ & 1 & & & & \\
\hline & $\begin{array}{l}\text { Sig. } \\
\text { Tailed) }\end{array}$ & & & & & \\
\hline Outsourcing & $\begin{array}{l}\text { Pearson } \\
\text { Correlation }\end{array}$ & $.263 * *$ & 1 & & & \\
\hline & $\begin{array}{l}\text { Sig. } \\
\text { Tailed) }\end{array}$ & 0.007 & & & & \\
\hline $\begin{array}{l}\text { Information } \\
\text { Technology } \\
\text { Adoption }\end{array}$ & $\begin{array}{l}\text { Pearson } \\
\text { Correlation }\end{array}$ & $.350 * *$ & $.346^{* *}$ & 1 & & \\
\hline & $\begin{array}{l}\text { Sig. } \\
\text { Tailed) }\end{array}$ & 0 & 0 & & & \\
\hline $\begin{array}{l}\text { Total Quality } \\
\text { Management }\end{array}$ & $\begin{array}{l}\text { Pearson } \\
\text { Correlation }\end{array}$ & $.363 * *$ & $.516^{* *}$ & $.543 * *$ & 1 & \\
\hline & $\begin{array}{l}\text { Sig. } \\
\text { Tailed) }\end{array}$ & 0 & 0 & 0 & & \\
\hline \multirow[t]{2}{*}{$\begin{array}{l}\text { Performance } \\
\text { of World Bank } \\
\text { funded } \\
\text { projects }\end{array}$} & $\begin{array}{l}\text { Pearson } \\
\text { Correlation }\end{array}$ & $.509 * *$ & $.398 * *$ & $.678 * *$ & $.685^{* *}$ & 1 \\
\hline & $\begin{array}{l}\text { Sig. } \\
\text { Tailed) }\end{array}$ & 0 & 0 & 0 & 0 & \\
\hline
\end{tabular}

** Correlation is Significant at the 0.05 Level (2-Tailed). 
International Journal of Supply Chain and Logistics

ISSN 2520-3983 (Online)

Vol. 5, Issue No.2, pp 1 -20, 2021

www.carijournals.org

\subsection{Regression Analysis}

In this study multivariate regression analysis was used to determine the significance of the relationship between the dependent variable and all the independent variables pooled together. Regression analysis was conducted to find the proportion in the dependent variable (performance of World Bank funded projects in Kenya) which can be predicted from the independent variables (vendor optimization, outsourcing, information technology adoption, total quality management).

Table 6 presents the regression coefficient of independent variables against dependent variable. The results of regression analysis revealed there is a significant positive relationship between dependent variable and the independent variable. R square value of 0.647 means that $64.7 \%$ of the corresponding variation in performance of World Bank funded projects in Kenya can be explained or predicted by (vendor optimization, outsourcing, information technology adoption, total quality management) which indicated that the model fitted the study data. The results of regression analysis revealed that there was a significant positive relationship between dependent variable and independent variable at $(\beta=0.647), \mathrm{p}=0.000<0.05)$.

Table 6: Model Summary

\begin{tabular}{llllll}
\hline Model & $\mathrm{R}$ & R Square & Adjusted R Square & $\begin{array}{l}\text { Std. Error of the } \\
\text { Estimate }\end{array}$ \\
\hline 1 & $.805^{\mathrm{a}}$ & .647 & .633 & .166295 \\
\hline
\end{tabular}

a) Predictors: (Constant), Vendor Optimization, Outsourcing, Information Technology Adoption, Total Quality Management

b) Dependent Variable: Performance of World Bank funded projects

Table 7: ANOVA

\begin{tabular}{ccccccc} 
Model & & Sum of Squares & df & Mean Square & F & Sig. \\
\hline 1 & Regression & 5.027 & 4 & 1.257 & 45.449 & $.000^{\mathrm{b}}$ \\
& Residual & 2.738 & 99 & 0.028 & \\
& Total & 7.765 & 103 & & \\
\hline
\end{tabular}

The significance value is 0.000 which is less than 0.05 thus the model is statistically significance in predicting how vendor optimization, outsourcing, information technology adoption, total quality management influence performance of World Bank funded projects in Kenya. The F critical at 5\% level of significance was 26.5. Since F calculated which can be noted from the ANOVA table 
International Journal of Supply Chain and Logistics

ISSN 2520-3983 (Online)

Vol. 5, Issue No.2, pp 1 -20, 2021

$\underline{\text { www.carijournals.org }}$

above is 45.449 which is greater than the $\mathrm{F}$ critical (value $=26.5$ ), this shows that the overall model was significant. The study therefore establishes that; vendor optimization, outsourcing, information technology adoption, total quality management were all important strategic procurement influencing performance of World Bank funded projects. These results agree with Rotich (2017) results which indicated a positive and significant role of strategic procurement on performance of World Bank funded projects.

Table 8: Coefficients of Determination

\begin{tabular}{|c|c|c|c|c|c|c|}
\hline \multicolumn{2}{|c|}{ Model } & \multicolumn{2}{|c|}{$\begin{array}{l}\text { Unstandardized } \\
\text { Coefficients }\end{array}$} & \multirow{2}{*}{$\begin{array}{l}\text { Standardized } \\
\text { Coefficients } \\
\text { Beta }\end{array}$} & \multirow[t]{2}{*}{$\mathrm{t}$} & \multirow[t]{2}{*}{ Sig. } \\
\hline & & $\mathrm{B}$ & Std. Error & & & \\
\hline \multirow[t]{5}{*}{1} & (Constant) & 2.353 & 0.202 & & 11.619 & 0.000 \\
\hline & Vendor Optimization & 0.183 & 0.037 & 0.392 & 4.948 & 0.000 \\
\hline & Outsourcing & 0.158 & 0.045 & 0.232 & 3.546 & 0.001 \\
\hline & $\begin{array}{l}\text { Information Technology } \\
\text { Adoption }\end{array}$ & 0.121 & 0.023 & 0.383 & 5.272 & 0.000 \\
\hline & Total Quality Management & 0.001 & 0.036 & 0.001 & 0.021 & 0.040 \\
\hline
\end{tabular}

a) Predictors: (Constant), Vendor Optimization, Outsourcing, Information Technology Adoption, Total Quality Management

b) Dependent Variable: Performance of World Bank funded projects

The research used a multiple regression model

$\mathbf{Y}=\boldsymbol{\beta}_{0}+\boldsymbol{\beta}_{1} \mathbf{X}_{1}+\boldsymbol{\beta}_{2} \mathbf{X}_{2}+\boldsymbol{\beta}_{3} \mathbf{X}_{3}+\boldsymbol{\beta}_{4} \mathrm{X}_{4}+\mathcal{E}$

The regression equation will be;

$\mathrm{Y}=2.353+0.183 \mathrm{X}_{1}+\mathbf{0 . 1 5 8}_{2}+\mathrm{0.121}_{3}+\mathrm{0.001}_{4}$

The regression equation above has established that taking all factors into account (vendor optimization, outsourcing, information technology adoption and total quality management) constant at zero, performance of World Bank funded projects in Kenya will be an index of 2.353

The findings presented also shows that taking all other independent variables at zero, a unit increase in vendor optimization will lead to a 0.158 increase in performance of World Bank funded projects. The P-value was 0.001 which is less 0.05 and thus the relationship was significant. 
International Journal of Supply Chain and Logistics

ISSN 2520-3983 (Online)

Vol. 5, Issue No.2, pp 1 -20, 2021

www.carijournals.org

The study also found that a unit increase in outsourcing will lead to a 0.001 increase in performance of World Bank funded projects. The P-value was 0.04 and thus the relationship was significant. In addition, the study found that a unit increase in information technology adoption will lead to a 0.121 increase in performance of World Bank funded projects. The P-value was 0.000 and thus the relationship was significant. Lastly, the study found that organisational benchmarking will lead to a 0.183 increase in performance of World Bank funded projects. The P-value was 0.000 and hence the relationship was significant since the p-value was lower than 0.05 .

\section{0 SUMMARY, CONCLUSION AND RECOMMENDATIONS}

The study sought to examine the influence of public procurement and asset disposal Act on performance of executive state corporations in Kenya.

The study endeared to determine role of strategic procurement on performance of World Bank funded projects in Kenya. The regression results revealed that strategic procurement identified in the study, that is, vendor optimization, outsourcing, information technology adoption, and total quality management combined could explain approximately $64.7 \%$ of the variations in the performance of World Bank funded projects. The other $35.3 \%$ may be attributed to other strategies not explained by the model or the variables.

\section{Conclusion}

Based on the study findings, the study concludes that performance of procurement on performance of World Bank funded projects can be improved by vendor optimization, outsourcing, information technology adoption, and total quality management.

\section{Recommendations}

The study recommends that procurement staff in the World Bank funded projects should ensure that they strictly follow procurement procedures to ensure that goods supplied are of the right quality, in the right quantity, at the right time, to the right place from the right source. This will aim at satisfaction of customers in terms of cost, quality, and timeliness of the delivered product or service, minimizing administrative operating costs.

\section{References}

Aberdeen Group (2014). Supply chain inventory strategies benchmark report: how inventory misconceptions and inertia are damaging companies' service levels and financial results, Aberdeen Group.

Agwaral, N. M. (2019). Model Deming's Quality principles to improve performance using interpretive structural Modeling and MICMAC analysis.

Alauddin N. \& Yamada S. (2019) Overview of Deming Criteria for Total Quality Management Conceptual Framework Design in Education Services, 3 (5), (12-20)

Amayi, F. K. (2011). Factors Affecting Procurement in the Public Service: a Case Study of the State Law Office. Eldoret: Moi University.

Andrew, M. (2012). Procurement Reforms in Kenya. Journal of Economics, 22(1), 23-50

Kasomo, D. (2011). Research Methods in Humanities and Education, Eldoret; Zapf Chancery. 
International Journal of Supply Chain and Logistics

ISSN 2520-3983 (Online)

Vol. 5, Issue No.2, pp 1 -20, 2021

$\underline{\text { www.carijournals.org }}$

Khan. M. a. (2010) Evaluating the Deming Management Model of Total Quality Telecommunication Industry in Pakistan - An Empirical Study, 47-48.

Kinyanjui, P. (2010). Procurement Challenges in Kenya. Journal of Procurement, 13(1), 65-85.

KIPPRA. (2010). The Demographic Governance Support Programme (DGSP). Nairobi: KIPPRA.

Kitheka, S. (2012). Inventory management automation and the performance of supermarkets in western Kenya, Unpublished MBA Project, University of Nairobi, Nairobi.

Knudsen, D. (2009). Improving procurement performance with E-business mechanisms. Lund University. Lund, Australia.

Thompson A., \& Strickland, A. (2010). Strategic Management. 12th Ed. United Kingdom: Business Publications, Plano.

USAID (2012). Selecting and implementing total quality management systems for public health supply chain: Deliver Project, USAID.

Wangari, B. (2012). Role of competitive strategies on the performance of hair salons in Nairobi. Unpublished MBA Project report, University of Nairobi.

Water, D. (2013). Global logistics and distribution planning: strategies for management (4th edition), Kogan Page Limited, London.

Procurement Journal.

Rotich, L. M. (2011). Role of Planning on Procurement Performance in the Kenya, International Journal of Human Resource and Research Publication, 12 (4), 289-292.

Saleemi, N. A. (2010). Procurement and supplies Management Simplified. Nairobi: Saleemi Publications Limited.

Samuelson, O. (2013). The IT-Barometer-A Decade's Development of its Use in The Swedish Construction Sector. Journal of Information Technology in Construction, 13 (5), 1-19.

Talluri, W. (2012). Benchmarking the performance of English Universities", Benchmarking International Journal, 14 (1), 102-122.

Thompson A., \& Strickland, A. (2010). Strategic Management. 12th Ed. United Kingdom: Business Publications, Plano.

USAID (2012). Selecting and implementing total quality management systems for public health supply chain: Deliver Project, USAID.

Wangari, B. (2012). Role of competitive strategies on the performance of hair salons in Nairobi. Unpublished MBA Project report, University of Nairobi.

Water, D. (2013). Global logistics and distribution planning: strategies for management (4th edition), Kogan Page Limited, London. 